\title{
METHODS FOR IMPROVEMENT OF THE ECOSYSTEM SERVICES OF SOIL BY SUSTAINABLE LAND MANAGEMENT IN THE MYJAVA RIVER BASIN
}

\author{
LENKA KORBELOVVÁ ${ }^{*}$, SILVIA KOHNOVÁ
}

\begin{abstract}
The main aim of this study is the development of methods for the assessment of the ecosystem services (ESS) of soils within the RECARE project and the participatory identification of measures to combat soil threats caused by floods in the Myjava River basin. The Myjava Hills highlands are known for their rapid runoff response and related muddy floods, which are determined by both the natural and socio-economic conditions. Within the frame of the mentioned project, the ESS framework with detailed relationships between the ecology, societal response, driving forces and also human well-being was identified. Next, to assess the SLM practices in the pilot basin, the stakeholders, who showed an interest in solving the flood protection problems in their areas, took an active part in the process of evaluating, scoring and selecting the best sustainable land management practices (SLM) for the flood protection of soil. From the results which were proposed, the technology of vegetative strips was top rated within the total results among all the SLM measures in all the categories, followed by water-retaining ditches and small wooden dams. Building a polder least meets the proposed SLM criteria.
\end{abstract}

\section{Address}

1 Slovak University of Technology, Faculty of Civil Engineering, Department of Land and Water Resources Management, Bratislava, Slovakia (lenka.korbelova@stuba.sk)

2 Slovak University of Technology, Faculty of Civil Engineering, Department of Land and Water Resources Management, Bratislava, Slovakia (silvia.kohnova@stuba.sk)

* Corresponding author: lenka.korbelova@stuba.sk

\section{Key words}

- Ecosystem services,

- RECARE project,

- Myjava catchment,

- Stakeholders,

- flood protection.

\section{INTRODUCTION}

Nature provides us with products (such as wood) and services (such as influencing runoff and water quality), which are collectively known as "ecosystem services" (de Groot, 1992 Daily, 1997) or "eco-services" (Costanza et al., 2014). Ecosystem services are the benefits that people obtain from ecosystems. Ecosystems are a fundamental part of all of human life and the activities associated with it. The services and products they provide are essential for maintaining development as well as for future economic and social growth. In the last 35 years many measures have been adopted to respond to the pressures from non-governmental stakeholders to participate in the management of the public environmental resources of the European Union.
The term "ecosystem services" (the study of critical environmental problems or "SCEP") emerged in the early 1970s as a descriptive framework for structuring and synthesizing a biophysical understanding of ecosystem processes in terms of human well-being. The term "ecosystem services" is derived from the word "ecosystem", which in the Slovak Republic is defined in $\S 3$ of Act No. 17/1992 Coll. on the environment as a "functional system of living and non-living components of the environment that are interconnected by the exchange of substances, energy flow and information sharing that interact and develop in a particular space and time."

As many of these types of goods and services have always been freely available and have no market price, their true long-term value is not included in the economic estimates of a company. Experts have identified four different kinds of services essential to the health and 
prosperity of people. We divide ecosystem services into supporting (includes soil formation, photosynthesis and nutrient cycling, which underpin growth and production), provisioning (provides the goods themselves, for example, food, water, wood and fiber), regulating (regulates the climate, rainfall, and water (e.g., inundations), waste and disease), and cultural services (includes beauty, inspiration and recreation, which contribute to our peace of mind).

The ecosystem services of soils are various and valuable but are also not fully appreciated. As with all ecosystem services, they are classified into supporting, provisioning, regulating and cultural services. Soil manages the nutrient and water cycles. It is able to decompose waste and detoxifying agents and is a site for various microorganisms and fauna, which support its precious ecosystem services. Soil also sustains recreational activities, including our cultural heritage. The value of the ecosystem services of soils dominates other parts of the ecosystem, but the extent and value of the services derived from the soil ecosystem are not well understood. Three of the biggest challenges facing the development of ecosystem services are:

(a) A better understanding and development of the documentation of soil biodiversity,

(b) The development of a more complex economic assessment of soil services,

(c) An understanding of soil management methods with the aim of maximising their benefits for mankind.

The paper focuses on the methods for assessing the ecosystem services of soils (ESS) developed within the RECARE project and the methods for improving ESS by flood protection technologies. The results for the Myjava River basin, which was chosen in Slovakia as a representative pilot region for soil threatened by flooding, are presented here. The methodologies for the identification and selection of suitable technologies for the flood protection of soils, which are mainly based on land management, were developed by the group of researcher and "stakeholder involvement."

\section{ECOSYSTEM SERVICES OF SOIL IN THE RECARE PROJECT}

All the ecosystems in the world have soil functions; i.e., they depend on soil. Soil functions should be seen as components of soil processes, which provide inputs for the supply of final ecosystem services (Glenc et al., 2012).

The RECARE project (Preventing and Remediating the degradation of soils in Europe through Land Care) is a $7^{\text {th }}$ framework project of the European Union, which includes 17 case studies of threats to soil with the aim of studying various conditions which appear all over Europe. The aim of the RECARE project is to fill in the knowledge gaps about the operation of soil systems influenced by the climate and human activities, develop a harmonized methodology in order to evaluate the state of the soil degradation and preservation, develop a universally applicable methodology for the assessment of the impact of soil degradation on the soil functions and ecosystems, select innovative measures for cooperation between final users and assess their efficiency regarding soil functions and ecosystems, including costs and benefits, and assess methods for facilitating the acceptance of these measures by the final users (RECARE Workshop Report).

Various threats to soils as well as preventive measures aimed at their elimination have various impacts on soil functions and ecosystem services. These measures mitigate changes in soil characteristics and have an impact on other indicators, such as:

- bio-physical indicators (e.g., reduced soil loss)

- socio-economic indicators (e.g., increased production, reduced workloads).

The ecosystem services within the RECARE project will be evaluated based on the Conceptual Framework of RECARE for soil functions and ecosystem services (Fig.1). The chart in Fig. 1 has been developed based on various methodologies developed by writers dealing with the issue. In the RECARE project we would like to assess the various impacts on ecosystem services that threaten soil and propose measures for their elimination according to different spatial scales.

\section{ECOSYSTEM}

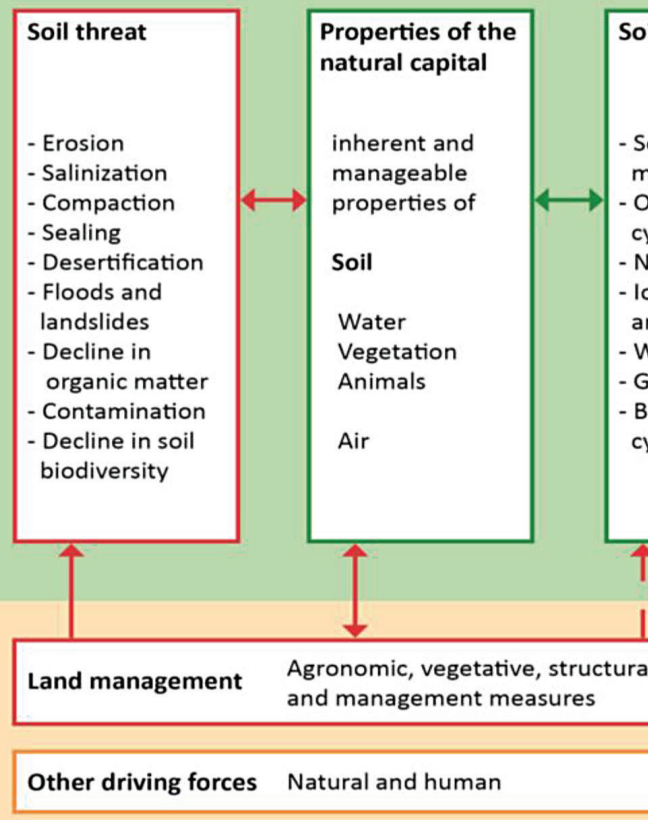

DRIVING FORCES
HUMAN WELLBEING

\begin{tabular}{|l|l|}
\hline $\begin{array}{l}\text { Soil function \& } \\
\text { Ecosystem } \\
\text { services } \\
\text { provisioning }\end{array}$ & \begin{tabular}{|l|}
\hline Benefits \\
E.g. \\
- Food/ fibre \\
- Drinking water \\
regulating and \\
maitenance \\
- Hazard \\
regulation \\
- Biodiversity \\
- Recreation/ \\
tourism \\
- Health and \\
well-being \\
- Inspirational and \\
spiritual \\
experience
\end{tabular} \\
\hline
\end{tabular}

Value

E.g.,

Use value

Non-use value

- Individual value - Social value
Organic matter

Nutrient cycling

and exchange

Water cycling

Gas cycling

Biological soil cycles 


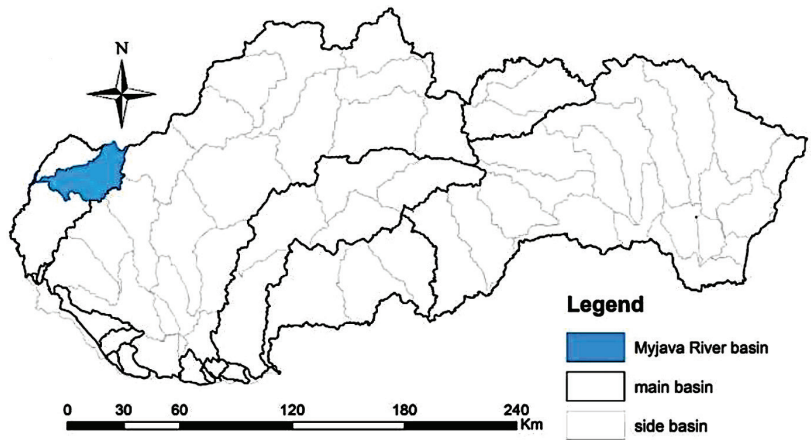

Fig. 2: Location of the Myjava River basin in Slovakia.

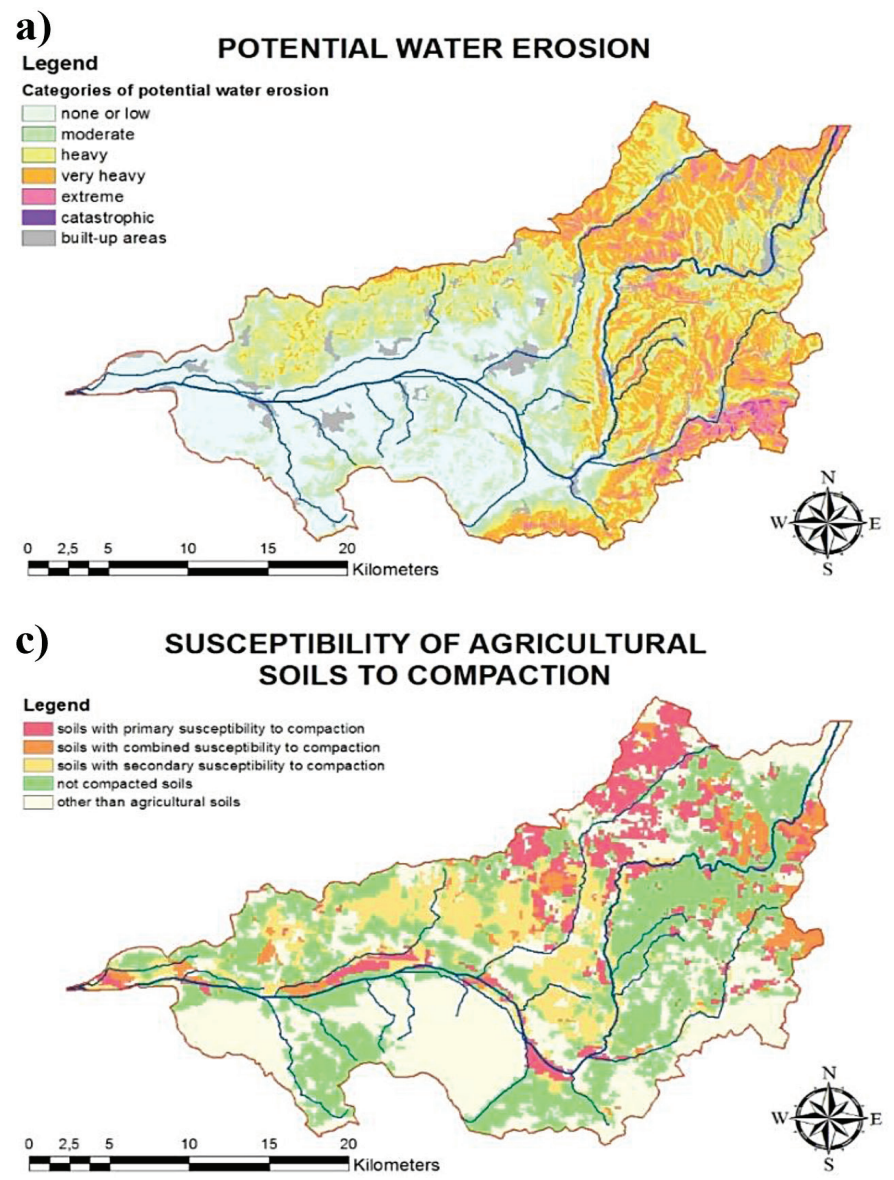

The sources and basic elements of the RECARE conceptual framework for soil functions and ecosystem services are based on the baseline methodologies mentioned in the sources under Figure 1. The main categories of ecosystem services are taken from the Millennium Ecosystem Assessment (MA, 2005); the adapted and simplified subcategories of ecosystem services are from TEEB (MA, 2003). The main structure of the "Cascade model" (Haines-Young, Potschin, 2009), feedback in the TEEB model (Braat, de Groot, 2012), the soil processes and benefits (Glenc et al., 2012), country management and social reactions (Van Oudenhoven et al., 2012), the natural capital with the natural and yielding characteristics of soil (Dominati et al., 2014), and the monitoring and assessment of ecosystems and their services (MAES, 2013) are also a part of the RECARE conceptual framework. b)

\section{ACTUAL WATER EROSION}

Categories of actual water erosion

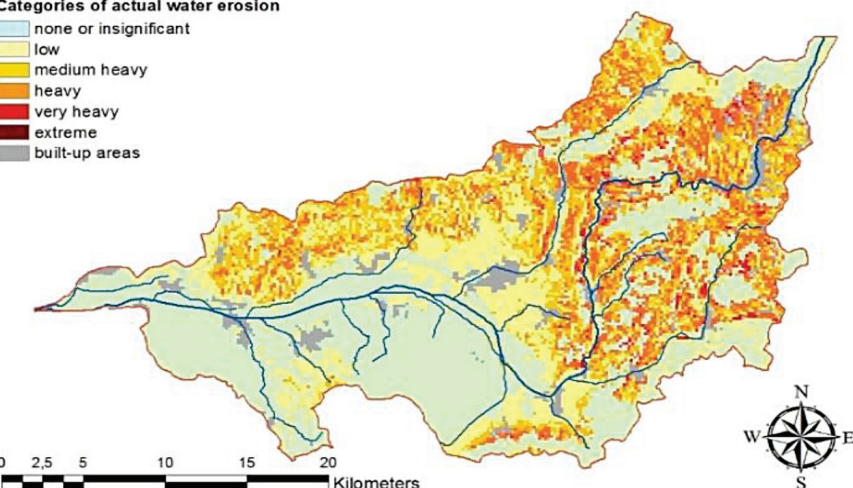

d) SOIL SUSCEPTIBILITY TO ACIDIFICATION

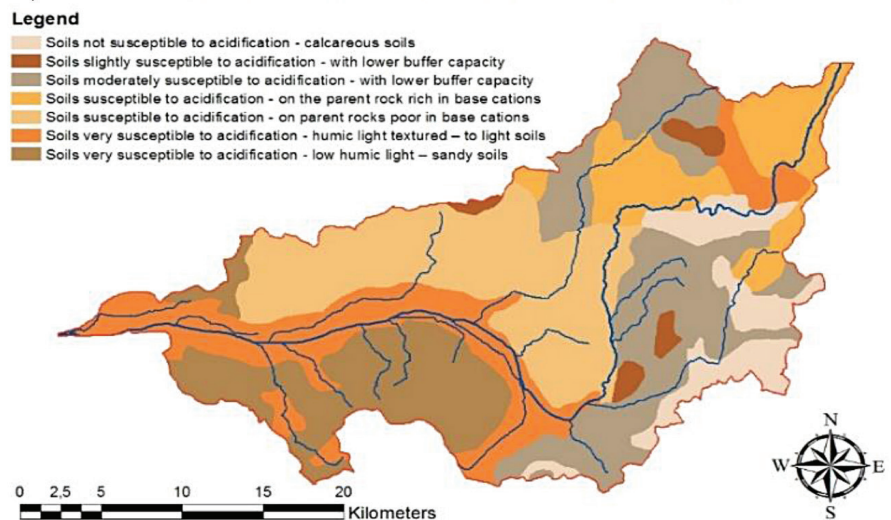

Fig. 3 a-d: Maps of various sources of soil threats. Source: WOCAT SLM DATABASE, Atlas krajiny Slovenskej republiky.
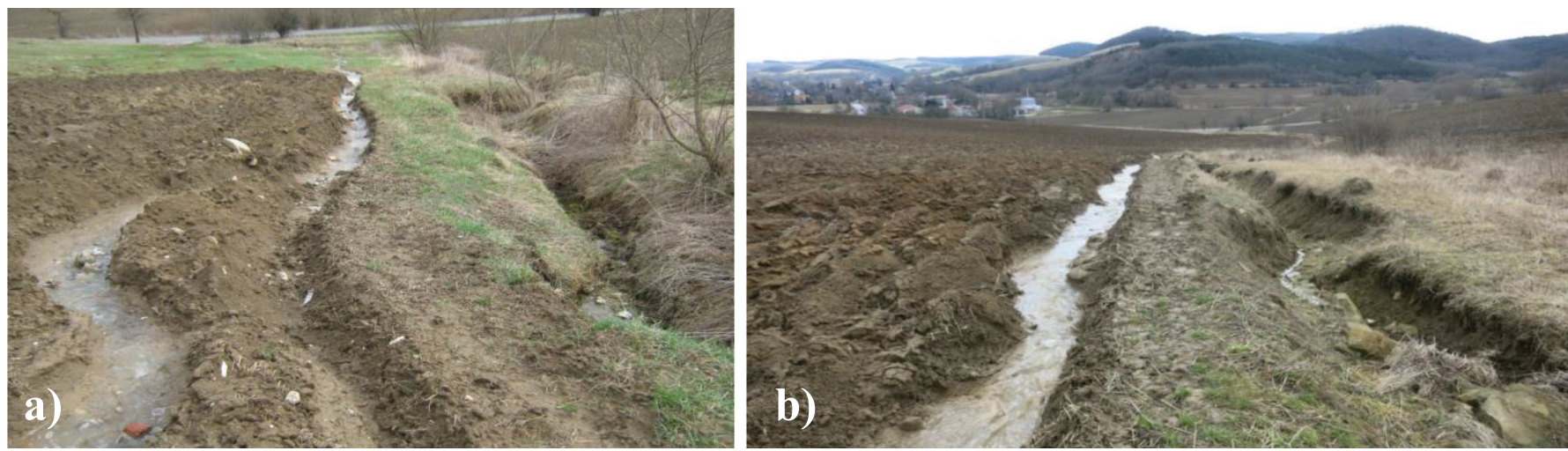

Fig. 4a-b.: Erosion rills (near the town of Myjava - Tura Luka) built up by bad agricultural practices. Photo, Kohnová, March 2015. 


\subsection{Case study of the Myjava River basin}

Of the 17 case studies selected for analysing various soil threats across Europe within the RECARE project, the Myjava river basin in Slovakia was chosen as a representative region for soil threatened by flooding and soil erosion. The Myjava River basin is located in the western part of Slovakia, Fig.2, and is known for a rapid runoff response and related muddy floods, which are determined by both the natural and socio-economic conditions. The present-day cultural landscape of the Myjava Hills is the result of approximately 600 years of the anthropogenic transformation of the naturally forested landscape. The drivers for this flood-prone regime, which also lead to flash floods, include impervious subsoils, frozen subsoil, extreme variability in precipitation, and adverse land use changes.

The spatial variability of the soil in the catchment is mainly caused by the substrate and terrain. The upper parts of the catchment, which have higher inclinations of the relief, are mostly comprised of Cambisols which are patchily mixed with Calcaric Cambisols. The area around the town of Senica is formed by Haplic Luvisols, and the vicinity of the River Myjava is formed by Fluvisols and light Arenosols, which are mainly represented by sandy soils. The structure of the soil in most of the basin is predominantly loamy with some sandy soil in its southwestern part. The permeability of the soils is predominantly medium with some areas around the confluence of the Rivers Myjava and Morava having high values and a small area around the town of Myjava having slightly lower values. In the largest part of the catchment, the soil reaction defining the $\mathrm{pH}$ of the soils is slightly alkaline to neutral with the $\mathrm{pH}$ in a range of 6.5 to 8 . Only the areas in the southern part of the catchment with coniferous vegetation have extremely acidic soil with a $\mathrm{pH}$ of around 4.5-5.5. The soil moisture regime of this soil ranges from slightly moist (the northern part) to slightly dry (the southern part). In the study area the agricultural land is mainly used for crop production and partly used for grazing livestock.

Floods with a high concentration of eroded material generate muddy deposits. These processes represent significant environmental and natural hazards in the conditions of the Myjava region. Among other sources of the soil threats are the deforestation and agricultural cultivation of extensive areas, which have caused an enormous intensification of the originally natural landscape-forming processes and erosion from tillage. The combination of adverse hydrological conditions, such as impervious subsoils, frozen subsoil, and changes in extreme precipitation, have led to the development of gullies. These processes increase the slow and harmful geomorphic changes, leading to erosion from tillage and gullies, and increasing the risk of flash floods. Maps of some of the main sources of the soil threats are shown in Figure 3.

Some visible effects of the soil degradation are due to water erosion on the agricultural land. Fig. 4 a,b presents an example of the development of erosion rills on the agricultural land, mostly on the steep hills. This effect is caused by bad agricultural practices i.e., mostly tillage along the slopes.

\section{METHODS FOR THE IMPROVEMENT OF ESS IN THE MYJAVA RIVER BASIN}

The methodology for assessing soil ecosystem services for the Myjava River basin and proposals for improving ESS by flood protection technologies is being developed through consultations with the end users, i.e., the stakeholders, by using their knowledge and opinions about the soil threats and protection of the soil as well as the ecosystem services of the soil. Two groups of stakeholders i.e., external and internal, are involved in the project, see Fig. 5 a,b. During the years 2015-2016, two stakeholder workshops and lots of small meetings with the stakeholders were held. The mostly local stakeholders, who were $75 \%$ of all the participants, showed great interest in the project and took an active part in the meetings and workshops.

Out of the discussion with the stakeholders during the second workshop (Report SW2, 2015), a total of 6 technologies were suggested for the protection of soil against floods and erosion: vegeta-

\section{LEGEND:}

ME - Ministry of the Environment

SHMU - Slovak Hydrometeorological Institute

NGOs - Non-governmental Organisations

SWE - The Slovak Water Management Enterprise

SWE $B_{n}$ - The Slovak Water Management Enterprise - Sub-basin

$\mathbf{M C}_{n}$ - Major of the Town

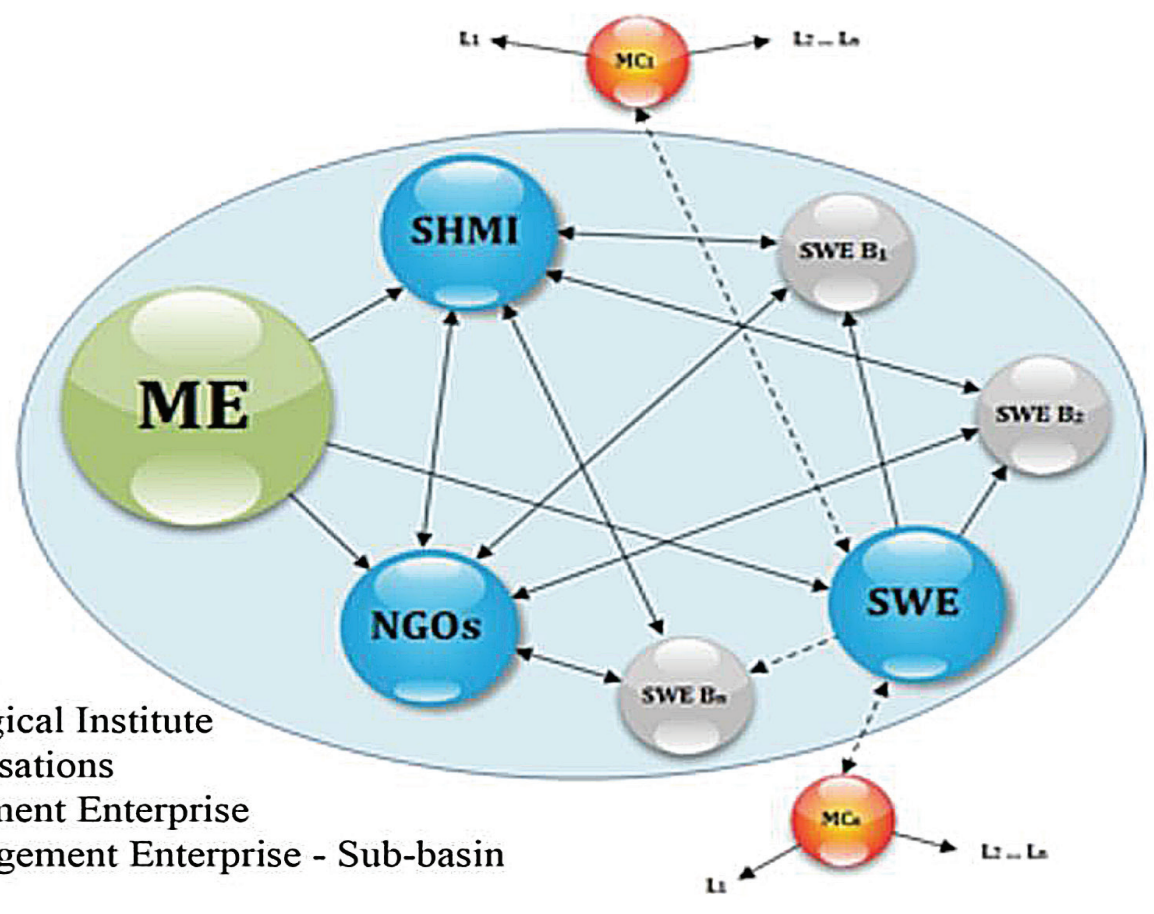

$\mathbf{L}_{\mathbf{n}}$ - Local individuals (population)

Fig. 5a: Stakeholder network. External stakeholders. Source: RECARE Stakeholder workshop. 


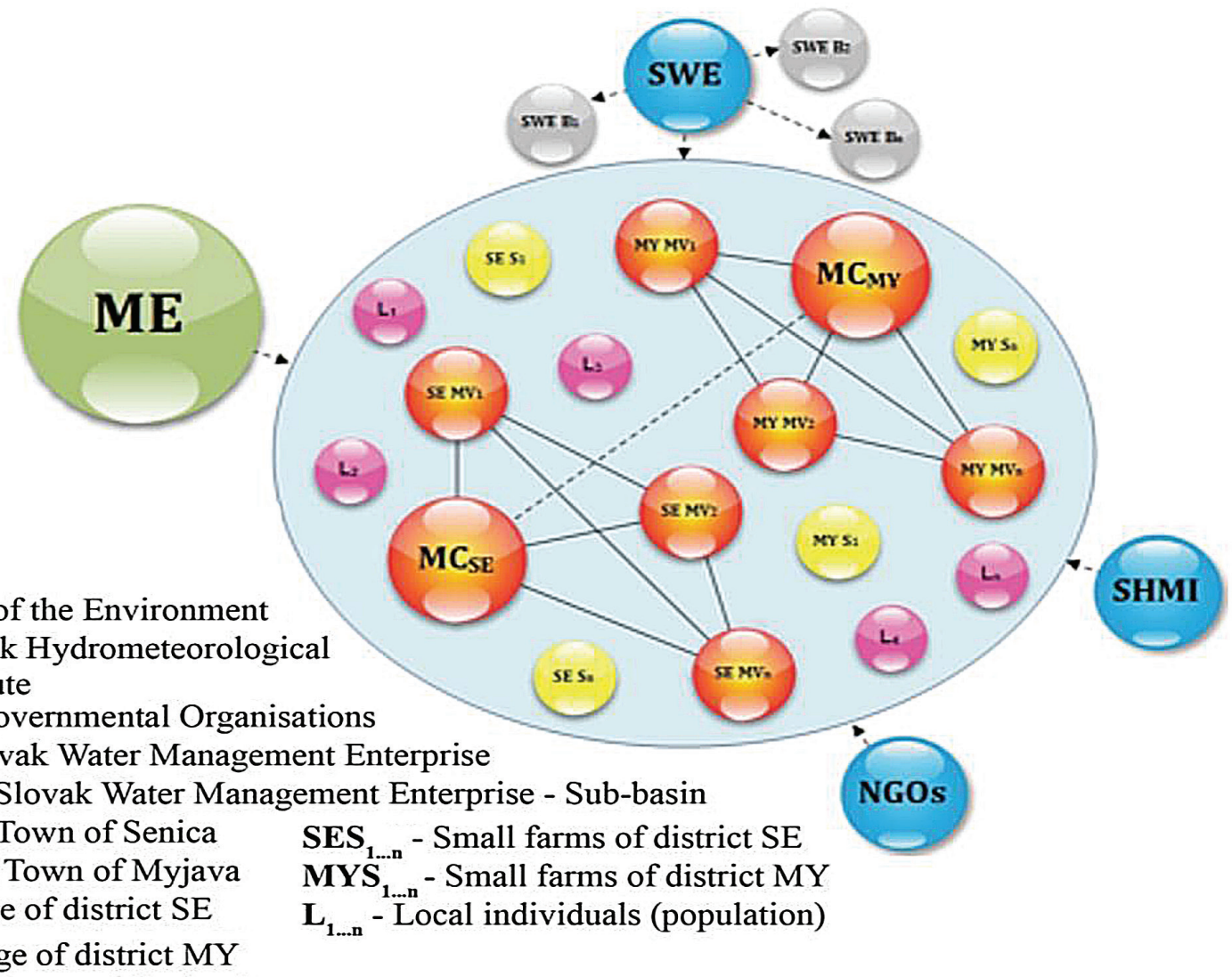

LEGEND:

ME - Ministry of the Environment

SHMU - Slovak Hydrometeorological Institute

NGOs - Non-governmental Organisations

SWE - The Slovak Water Management Enterprise

SWE $B_{n}$ - The Slovak Water Management Enterprise - Sub-basin

$\mathbf{M C}_{\mathbf{S E}}-$ Mayor Town of Senica

$\mathbf{M C}_{\mathbf{M Y}}$ - Mayor Town of Myjava

SES $_{1 . . \mathrm{n}}$ - Small farms of district SE

SEV $_{1 . . . n}$ - Village of district SE

MYV $\mathbf{1}_{1 . . \mathrm{n}}$ - Village of district MY

$L_{1 \ldots . n}$ - Local individuals (population)

Fig. 5b: Stakeholder network. Internal stakeholders. Source: RECARE Stakeholder workshop.

Tab. 1: Proposed criteria for assessment of Sustainable Land Management (SLM) technologies on the Myjava River basin. Source: Stakeholder workshop 2, RECARE, 2015.

\begin{tabular}{|c|c|c|}
\hline Category: economic & Category: socio-cultural & Category: ecological \\
\hline low cost & $\begin{array}{l}\text { increased cultural and aesthetic per- } \\
\text { ceptions of the country }\end{array}$ & increased soil moisture \\
\hline increased crop yield & increased recreational opportunities & decreased surface runoff \\
\hline increased fodder production & $\begin{array}{l}\text { improved food security / self-sufficien- } \\
\text { cy (reduce dependence on ext. support) }\end{array}$ & decreased soil loss \\
\hline increased animal production & $\begin{array}{l}\text { improved suitability for small holders / } \\
\text { large-scale land users }\end{array}$ & raised groundwater table/aquifer \\
\hline increased wood production & less damage to neighbours'fields & $\begin{array}{l}\text { improved resilience adverse events (drought, floods } \\
\text { storms, etc.) }\end{array}$ \\
\hline $\begin{array}{l}\text { increased availability of irrigation water } \\
\text { (groundwater, springs) }\end{array}$ & $\begin{array}{l}\text { less damage to public/private infra- } \\
\text { structure }\end{array}$ & reduction of flood risks \\
\hline increased farm income & $\begin{array}{l}\text { improved conditions for small and } \\
\text { large-scale land users }\end{array}$ & decreased downstream siltation/sediment yields \\
\hline increased diversification of income sources & & decreased off-site groundwater/ river pollution \\
\hline decreased soil loss & & decreased wind-transported sediments (off-site) \\
\hline $\begin{array}{l}\text { improved suitability for local socio-economic } \\
\text { conditions (e.g., crop system, market orienta- } \\
\text { tion, etc.) }\end{array}$ & & increased biomass / above ground C \\
\hline less damage from floods & & $\begin{array}{l}\text { increased soil organic matter / improved C seques- } \\
\text { tration }\end{array}$ \\
\hline increase the value of land & & decreased soil compaction \\
\hline \multirow[t]{2}{*}{ economic (in)equity } & & decrease in invasive alien species \\
\hline & & increase in habitat diversity / fragmentation \\
\hline
\end{tabular}


Tab. 2: Criteria selected and their rankings. Source: Stakeholder workshop 2, RECARE, 2015.

\begin{tabular}{|c|c|c|}
\hline Criteria & Category & Number of votes (importance) \\
\hline low cost & economic & 11 \\
\hline increased cultural and aesthetic perception of the country & socio-cultural & 8 \\
\hline decreased soil loss & ecological & 3 \\
\hline less damage to public/private infrastructure & socio-cultural & 3 \\
\hline reduction of flood risks & ecological & 7 \\
\hline decreased surface runoff & ecological & 3 \\
\hline improved resilience to adverse events (droughts, floods, storms, etc.) & ecological & 5 \\
\hline less damage from floods & economic & 3 \\
\hline improved conditions for small and large-scale land users & socio-cultural & 2 \\
\hline
\end{tabular}

Tab. 3 Scoring results, experimental. Source: Stakeholder workshop 2, RECARE, 2015.

\begin{tabular}{|c|c|c|c|c|c|c|}
\hline \multirow[t]{2}{*}{ Scoring results } & \multicolumn{2}{|l|}{ Experimental } & \multirow[b]{2}{*}{ ecological } & \multirow[b]{2}{*}{ ecological } & \multirow[b]{2}{*}{ socio-cultural } & \multirow[b]{2}{*}{ economic } \\
\hline & socio-cultural & economic & & & & \\
\hline Number of votes/ Importance & 11 & 8 & 7 & 5 & 3 & 3 \\
\hline Base criteria & $\begin{array}{l}\text { increased cultur- } \\
\text { al and aesthetic } \\
\text { perceptions of the } \\
\text { country }\end{array}$ & low cost & $\begin{array}{l}\text { reduction of } \\
\text { flood risks }\end{array}$ & $\begin{array}{l}\text { improved resilience } \\
\text { to adverse events } \\
\text { (droughs, floods, } \\
\text { storms etc.) }\end{array}$ & $\begin{array}{l}\text { less damage to } \\
\text { public/private } \\
\text { infrastructure }\end{array}$ & $\begin{array}{l}\text { decreased soil } \\
\text { loss }\end{array}$ \\
\hline vegetative strips & 5 & 5 & 5 & 5 & 4 & 5 \\
\hline water-retaining ditches & 3 & 4 & 4 & 4 & 4 & 4 \\
\hline small wooden dams & 3 & 4 & 3 & 4 & 4 & 3 \\
\hline polders & 3 & 2 & 4 & 3 & 5 & 1 \\
\hline
\end{tabular}

tive strips, drainage ditches, water-retaining ditches, small wooden dams, polders, and terracing. In some cases the selected technologies had already been realized in the basin; therefore, it is necessary to test and evaluate their efficiency. Subsequently, criteria from three categories (economic, socio-cultural and ecological) were proposed. The stakeholders discussed the criteria and chose the most important criteria from all the categories which are to be used. An overview of the selected criteria is presented in the Tab. 1.

A summary of how the stakeholders voted for the selected criteria is presented in Tab. 2. According to the given criteria, low costs, the enhancement of the cultural and aesthetic perceptions of the region, and the reduction of severe flood risks had the greatest number of votes.
The given measures were assessed in the form of a game based on the selected criteria. Next, the stakeholders were divided into groups according to their flood protection interests and professional orientations. Each group assigned points to the individual measures, and the partial outputs of the individual groups were averaged, see Table 3.

The score 1.00 is the most important, whereas the score 0.00 is the least important. The results are presented in Figure 5. The technology of vegetative strips is top rated among the total results of all the measures of SLM in all the categories. Water-retaining ditches and small wooden dams have similar values (from 0.5 to 0.75 ). Based on the selected criteria, polders were assessed as the least suitable measure, even though their assessment in two thirds of the assessments was more than 0.50

Tab. 4 Scoring results, normalised. Source: Stakeholder workshop 2, RECARE, 2015.

\begin{tabular}{|l|l|l|l|l|l|l|}
\hline Base criteria & $\begin{array}{l}\text { increased cultural and } \\
\text { aesthetic perceptions of } \\
\text { the country }\end{array}$ & $\begin{array}{l}\text { low } \\
\text { cost }\end{array}$ & $\begin{array}{l}\text { reduction of improved resilience to } \\
\text { the flooding } \\
\text { risks }\end{array}$ & $\begin{array}{l}\text { less damage to } \\
\text { adverse events (droughts, } \\
\text { floods, storm, etc.) }\end{array}$ & $\begin{array}{l}\text { decreased } \\
\text { public/private } \\
\text { infrastructure }\end{array}$ \\
soil loss
\end{tabular}




\section{vegetative strips}

Score

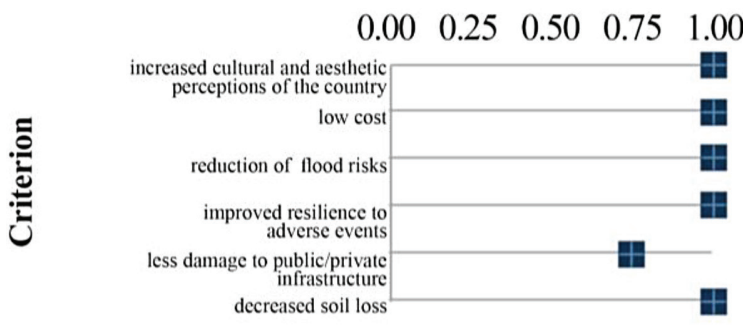

\section{small wooden dams}

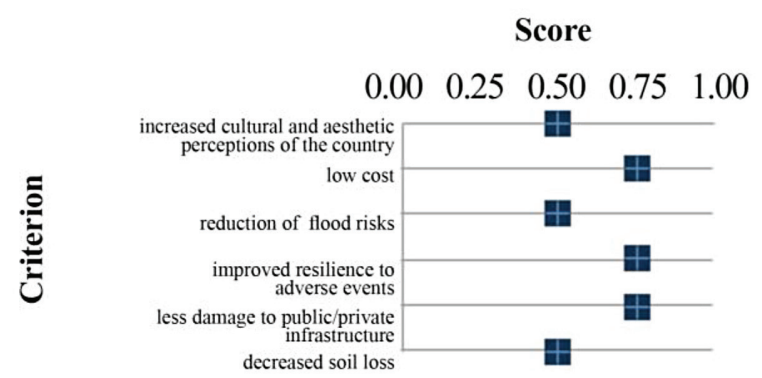

\section{water-retaining ditches}

Score

$\begin{array}{lllll}0.00 & 0.25 & 0.50 & 0.75 & 1.00\end{array}$

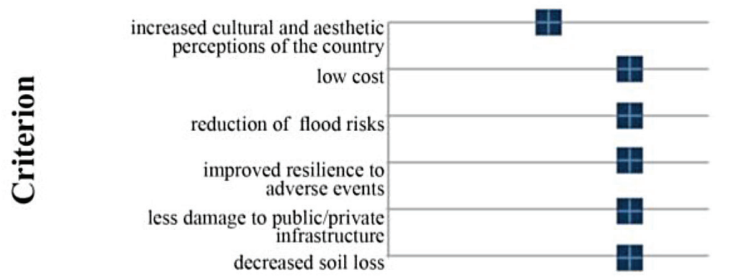

polders

Score

$\begin{array}{lllll}0.00 & 0.25 & 0.50 & 0.75 & 1.00\end{array}$

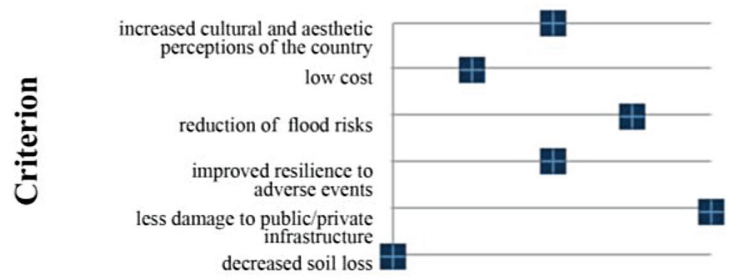

Fig. 6: Overview of scoring results per SLM practice - vegetative strips, water-retaining, small wooden dams, polders. Source: Stakeholder workshop 2, RECARE, 2015.

The most suitable measure from an economic point of view is vegetative strips and the least suitable measure from an economic point of view is a polder Fig. or the stakeholders also gave the best score to vegetative strips in terms of socio-cultural and ecological criteria. The stakeholders agreed that polders least meet the criteria. The results are shown below (Fig. 7, 8.).

\section{CONCLUSIONS}

Biodiversity as a part of ecosystems has an important role in providing goods and services for human well-being (MA, 2003). It is also certain that changes in biological diversity can have an impact on the provision of ecosystem services as well as many aspects of an ecosystem's stability, activity and sustainability (Constanza et al., 2007). Some aspects of biodiversity are actually considered to be independent ecosystem services, such as the locus (habitat) of service (Hein et al., 2006), protection of the gene pool, biological treatment against pests (De Groot et al., 2010), and pollination and dispersion of seeds (MA,2003).

A review of present studies shows that ecosystem services is a burning issue nowadays. It is necessary to do everything for the protection of biodiversity and related ecosystems, especially ecosystem services for people. In the frame of the mentioned project the ESS
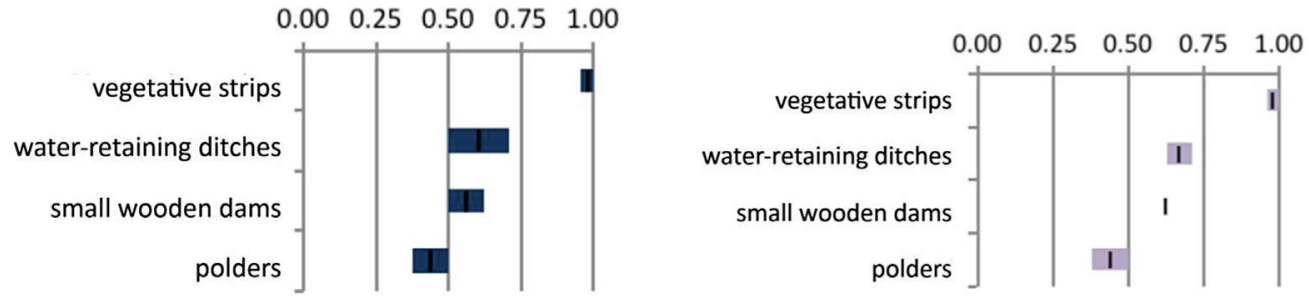

Fig. 7: Overall results for all the SLM practices in all the categories and in the economic category. Source: Stakeholder workshop 2, RECARE, 2015.
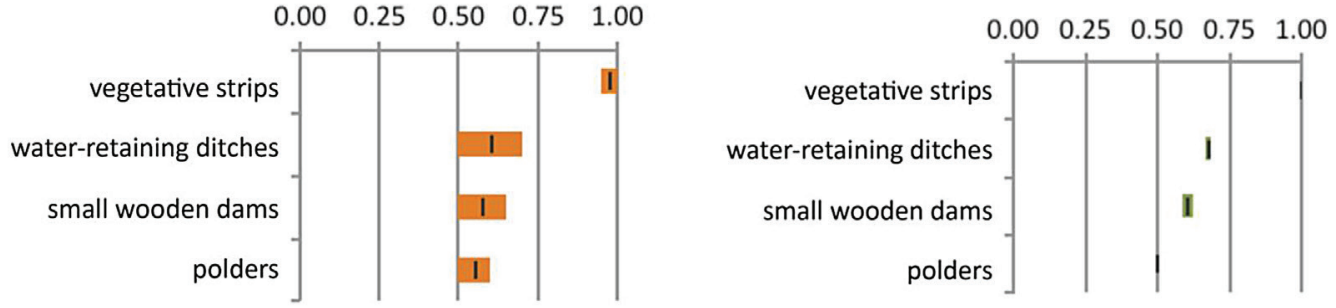

Fig. 8: Overall results for all the SLM practices in socio-cultural category and in ecological category. Source: Stakeholder workshop 2, RECARE, 2015. 
framework with detailed relationships among the ecology, societal response, driving forces and also human well-being were identified.

Next, we demonstrated the methods for detecting and evaluating SLM using stakeholder involvement.

The results from the stakeholders' involvement permit us to say that according to the stakeholders, the main causes of the threats to the Myjava catchment are floods. Agricultural technologies in the fight against soil loss resulting from erosion could have been implemented for many years (mitigation of ploughing, vegetated strips, drains). Many technologies were discussed at the workshop, and some of them were selected for potential experiments and testing. The local stakeholders were interested in the proposed measures and technologies for the protection of soil against flooding in their area. There was a general scepticism in the discussion about the financing and resolution of property and legal relationships, which limit the implementation of flood protection.
The technology of vegetative strips is top rated within the total results among all the measures of the SLM in all of the categories and was more popular than water-retaining ditches and small wooden dams. The stakeholders finally agreed that polders least meet their criteria.

\section{Acknowledgements}

This work was supported by the EU-FP7 RECARE project under the 603498 project ID, the Slovak Research and Development Agency under Contract No. 15-0497 and VEGA grant No. 1/0710/15. The authors thank the agencies for its research support.

\section{REFERENCES}

Braat, L. C. - de Groot, R. S. (2012) The ecosystem services agenda: bridging the worlds of natural science and economics, conversation and development, and public and private policy. In: Ecosystem services, ISSN: 2212-0416, No. 1, pp. 4-15.

Costanza, R. - Fisher, B. - Mulder, K. - Liu, S. - Christopher, T. (2007) Biodiversity and ecosystem services: A multi-scale empirical study of the relationship between species richness and net primary production. Ecological Economics 61, pp. 478-491.

Daily, G. (1997) Nature's Services: Societal Dependence on Natural Ecosystems. Island Press, Washington DC.

de Groot, R. S. (1992) Functions Of Nature: Evaluation of Nature in Environmental Planning, Management and Decision-Making. Wolters Noordhoff BV, Groningen pp. 345.

Dominati E. J. et al. (2014) Soil natural capital quantification by the stock adequacy method. In: Geoderma, ISSN 0016-7061.

Braat,L. C. - de Groot, R. S. (2012) The ecosystem services agenda: bridging the worlds of natural science and economics, conversation and development, and public and private policy. In: Ecosystem services, ISSN: 2212-0416, Č́́slo. 1, pp. 4-15.

de Groot, R. S. - Alkemade, R. - Braat, L. C. - Hein, L. - Willemen, L. (2010b) Challenges in integrating the concept of ecosystem services and values in landscape planning, management and decision making. Journal of Ecological Complexity 7 (3), 260-272.

EU, (2011) The EU Biodiversity Strategy to 2020. European Commission. Luxembourg, pp. 1-28.

Fazekašová, D. (2009) Soil - the basic component of the environment. In: Environmental Chemistry, ISBN 978-80-555-0082-9, p.251.
Glenc, K. et al. (2012) Deliverable D3.1: Soil and Soil Organic Carbon within an Ecosystem Service Approach Linking Biophysical and Economic Data, p. 33.

Haines-Young, R. - Potschin, M. (2009) The Links Between Biodiversity, Ecosystem Services and Human Well-Being. In: Raffaeli, D., Frid, C. (Eds.), Ecosystem Ecology: a new synthesis. BES ecological review series. Cambridge University Press (CUP), Cambridge.

Haines-Young, R. - Potschin, M. (2012) Common International Classification of Ecosystem Services (CICES). European Environment Agency, pp. 1-17.

Hein et. al. (2006) Spatial scales, stakeholders and the valuation of ecosystem services. In> Ecological Economics, ISSN: 09218009, pp. 209-228.

MA (2003) Ecosystems and Human Well-being: A Framework for Assessment. Millenium Ecosystem Assessment, Washington D.C.

MA (2005) Millenium Ecosystem Assessment - Ecosystems and Human Well-Being.

Maes, J. (2013) Mapping and Assessment of Ecosystems and Their Services. European Commission, pp. 1-81.

RECARE Stakeholder Workshop Report (2015) Selection of practicies to be tested and evaluated, Stakeholder workshop 2.

TEEB Foundations (2010) TEEB-The Economics of Ecosystems and Biodiversity (TEEB): Ecological and Economic Foundations. Earthscan, London

Van Oudenhoven et al. (2012) Framework for systematic indicator selection to assess effects of land management on ecosystem services. In: Ecological Indicators, ISSN: 1470-160X, pp.110-122. 